\title{
THE CORRELATION BETWEEN EFL LEARNERS' SPEAKING COMPETENCY AND THE USE OF PODCASTS
}

\author{
HERNING BUDIASTONO
}

Universitas Panca Sakti Bekasi

E-mail: hbudiastono@gmail.com

\begin{abstract}
Speaking is one of the important parts of communication. Every EFL learners have to master this skill. Use podcasts in improving their speaking skills is one method that helps them to learn it in an easy way. This study explored that podcast gave a contribution toward the speaking competency of vocational high school students. The finding showed that the correlation of podcasts as the independent variable $(\mathrm{X})$ and speaking as the dependent variable was positive. It indicated that podcast has a positive contribution to EFL learners' speaking competency.

Key Words : EFL Learners, Speaking Competency, Podcast
\end{abstract}

\section{INTRODUCTION}

Language is used as a tool for communication, (Rao, P. S. (2019:8). People use it to communicate to each other. They convey information, share their ideas, and make arguments to others. As Rahman, M. M. (2010:2) stated "Communication is a dynamic interactive process that involves the effective transmission of facts, ideas, thoughts, feelings and values". In order to make other people understand the message from a communication, a speaker need to be able to express his or her ideas properly. The way of delivering a message have to be clear enough to make the listener responds it properly therefore communication can run well. As Rahman, M. M. (2010:3) said that communication is an exchange of meaning and understanding. It means that people need to use the language that can be understood by both sides.

English, being the first world language, is said to be the first global lingua franca and it is the most widely used language in the world in international trade, diplomacy, mass entertainment, international telecommunications and scientific publications as well as publishing newspapers and other books, (Rao, P. S., 2019:66). English is one of the languages in the world that is used by people around the world to communicate. In accordance with that reason, students in Indonesia have to learn English. They start to study it from elementary school, but some of them start learning English from kindergarten. However, there are still many students with difficulty in learning it. They do not know how to express their ideas in English because they do not know the English words. Accordingly, speaking English is hard for them to learn.

"Speaking is one of the most difficult skills language learners have to face, (Bueno, Madrid, and Mclaren [2006: 321] in Rao, P.S., 2019:8). However, "Speaking is one of the basic language skills that have to be mastered by English foreign learners due to its significant and its use for communication", (Dewi, R. S., Kultsum, U., \& Armadi, A. (2017:63). They said that it is very important to be able to speak English regarding that it is the most commonly accepted language in the world so that it will be very beneficial for those who comprehend it not only to improve their knowledge and skills but also easier for them to get a job. More than that, they will not find it difficult to communicate and interact with people around the world when they travel (Gard \& Gautam, [2015] in Dewi, R. S., Kultsum, U., \& Armadi, A., 2017:63). Therefore, The mastery of speaking skills is viewed as a necessity for most EFL and ESL learners (Richards, [2008, p. 19]; Florez, [1999] in Ounis, A. (2017:96).

Learning any new language requires hard work, commitment and a willingness to make mistakes -- and English is no different, (Jabbarova, A., 2020). There are some factors that make students having difficulties in learning to speak English. Mostly, the method of teaching does not attractive to students. It is difficult for them to understand the materials that are delivered by the teacher. They get bored and lazy to speak. They prefer to focus on other things beside 
teaching process. The goal of the learning process can surely not be reached by them. It certainly causes the students have no opportunities to obtain new vocabularies and find out the right pronunciation in English. Those cases lead to a quite serious problem. It becomes teachers' concern and consideration in determining a good method to solve this problem. Teachers need to create many kinds of interesting methods that help students learning to speak English easily. Therefore they are capable of improving their speaking skills.

One of the interesting methods in learning English is by podcast. "Recently podcasts generated a lot of interest due to their ability to be integrated into studying to improve student listening, speaking, and reading skills", (Chaikovska, O., Zbaravska, L., \& Bilyk, T. (2019:1916). They said that the review of the literature on podcasts showed that foreign academics were pioneers in the implementation of innovative teaching tools. Most listeners of the podcasts are young people. Accordingly, this method can be used to improve students' speaking skills. As the situation of pandemic, using podcast in learning English is the right choice. This learning condition makes students have to study from home. They continue their education through online learning via Zoom and Google meet. Students and teachers have to adapt to online teaching and online studying. Learning from home is different with regular classrooms, there are many obstacles during this online teaching. Students cannot have face to face learning that is important in speaking learning. They use devices and internet access in order to participate in online classes. It also makes them stress and bored. Besides, students cannot meet friends and teachers as in a conventional class. Hence, using podcasts during online learning is an easy way to teach speaking in many topics. Furthermore, students can access the podcast by using their media player or mobile phone at any time and anywhere. Since there are many podcasts options, it is easier for teachers to choose the podcast that is suitable to the material and easy for students to understand. Moreover, podcasts make students more familiar with topics of speaking such as a report, conversation, discussion, interview, and other things and provide the correct pronunciation and new vocabulary based on the specific subject and grammar.

\section{Literature Review}

\section{Speaking}

In order to achieve their objectives, aspirations, and goals, people must master communication skills. The skills play a vital role in today's society, and mastery of these skills is required to achieve success in one's chosen career. In order to communicate effectively in this global environment, speaking is the most important skill of the four language skills. Leong, L. M., \& Ahmadi, S. M. (2017:34) stated "Speaking is one of the most important skills to be developed and enhanced as meaning of effective communication". And Kosdian (2016) in Rifa'at (2018) in Parmawati, A., \& Inayah, R. (2019:43) claimed "Of all four simplex skills (listening, reading, speaking, writing) speaking seems to be the most important because people who know languages are referred to as 'speakers' of that language, as if speaking includes all other types know the language". In addition, Derakhshan, Khalili, \& Beheshti, (2016:178) explained "Speaking is a production skill that falls into two main categories: accuracy and fluency". Accuracy consists of the use of vocabulary, grammar and pronunciation through several activities, fluency takes into account "the ability to keep going when speaking spontaneously", (Gower, Philips, \& Walter [ 1995] in Derakhshan, Khalili, \& Beheshti, (2016:178). It means that speaking is the ability to communicate with the other people in accuracy and fluency; accuracy is the ability to pronounce clearly using the correct grammatical structure and vocabularies; fluency is the ability to speak in understandable way in order not to break down communication.

\section{Speaking Problems}

Speaking English is not an easy skill for EFL students. It takes a lot of effort to help students to master it. According to Riadil, I. G. (2020:32), there are many factors that may affect the students negatively in the learning process. First, the large numbers of students which 
usually consist of 30-35 students or more become problematic. Such section provides fewer opportunities for them to practice speaking. Richards \& Schmidt (2010) in Riadil, I. G. (2020:32) stated that class size affects the quality of instruction in which it should not exceed fifteen for most language classes. Second, students tend to conceal their mistakes and weakness to protect them from being laughed at. As a result, they are unwilling to speak English. Last, most teachers prefer teaching grammar to productive skills such as speaking and writing. This is supported by Musthafa (2001) in Riadil, I. G. (2020:32) statement that many teachers in Asia tend to focus their teaching on grammatical items and knowledge of syntax.

Furthermore, it supported by Ur (2012:117) that explains about factors that cause difficulty in speaking as follows:

1) Shyness and inhibition

Mostly EFL learners feel scared of making mistakes, fearing criticism while they participate in the classroom. Ur (2012:117) said that students who are usually inhibited in their speech practice are afraid to make mistakes, look weak and are afraid to say or do something. It does really disturb their personality.

If that is the case, teacher supposed to be made students feel comfortable by giving them freedom to speak and share their opinion without being judge by making them feel uncomfortable with the mistakes.

2) Nothing to say

Learners often argue that it is hard for them to think of anything to say. It is because the topic that given is not interest or lack of audio- visual materials. Therefore, teachers should think what is the appropriate materials for the EFL learners according to their level and preferences.

3) Low participation of individuals

Sometimes in a class there is only one person who dares to speak, or in a large group each student has a limited time to speak. So, there is a tendency that only a few students are dominant enough to dare to speak, others have little or no courage.

4) Mother tongue use

When students find groups with the same mother tongue, they tend to use their own language because it is faster and easier to understand, and less effort than use English. Ur (2012:118) states that if students spend most of their time speaking their own language, they will obviously have little opportunity to improve their speaking skills in English.

According to the statements above, the causes of speaking problems of students in teaching and learning process are 1) the large number of students in one class, 2) many students who conceal their mistakes and weakness to avoid being laughed by their friends, 3) most teachers prefer teaching grammar to productive skills.

\section{Podcast}

According to Drew (2017:202) "A podcast is a digital packet of audio which is generally part of a series, released at regular intervals and automatically downloaded to personal media devices when made available through Really Simple Syndication (RSS) feeds". He explained that although primarily designed for RSS feed downloads, they are also widely available for manual download online. And he added that since 2004, podcast aggregation sites like Juice, Spotify and iTunes have been the primary way in which podcasts have been hosted and distributed globally, providing consumption via both RSS and manual download means. From the other perspective's SZE (2006:116) defines that podcast are audio (sometimes video) programs on the Web which are usually update at regular intervals. Listeners can listen, subscribe, and have the latest episodes of their favorite podcasts program on the computer, mobile phone or other software programs such as Spotify, iTunes, etc. Ramli (2018:3) explains that podcast gives students flexibility when and where to learn at their desired learning pace and path. Furthermore, he said podcasts can be instantly downloaded, copied, shared, and even edited, granting learners more control on their competence and possession of their learning. 
According to him, it is an interesting way for students to learn in every situation without any visual clues. They can find their interesting topics and take the favorite, relevant and useful information as their ideas for listening and speaking.

\section{Benefit of Podcast}

A podcast is one of the interactive media applied to help the learning process in developing language skills. Hasan \& Hoon on Ramli (2018:4) defines that engaging podcast in students' learning activities can develop academic performance, motivation, and promote learning. They also explained that it can also fasten learners' listening skills but other language components as well like pronunciation, vocabulary, grammar, speaking and related learning activities. According to SZE (2006:121) indicating the advantages in using podcast for speaking competency as follows:

1) Increase students' motivation and confident. It makes learning easier, faster and more attractive to the learners.

2) Improve students' pronunciation accuracy

3) Provide different tasks or podcast according to students' ability level

4) Help to teach in a large class by e-learning.

\section{RESEARCH METHODOLOGY}

The method of this research used quantitative research. The use of this method was to find out correlation between EFL learners speaking competency as a variable dependent (Y) and the using of podcast as an independent variable (X).

\section{Participants}

The population of this research was the eleventh-grade students of Mutiara 17 Agustus Vocational High School with a total number of 98 students in four different classes; pharmacy, health analysis, multimedia, and computer network engineering. As the sample of the research took thirty students of computer network engineering students from the population randomly.

\section{Instrument}

This study conducted a test as the instrument for obtaining data of speaking competency (dependent variable) and a questionnaire as the instrument for obtaining data of podcasts (independent variable).

\section{Data analysis}

For analyzing the data, it used descriptive and inferential analysis. The statistical calculation was via SPSS (Statistical Product and Service Solutions).

\section{Result and Discussion \\ Description of Data}

Descriptive analysis is the first process before starting the basic statistical calculations. It calculates the mean, the median, and the standard deviation of the collected data.

Table 1 Description Analysis

Descriptive Statistics

\begin{tabular}{|l|r|r|r|r|r|r|}
\hline & N & Minimum & Maximum & Sum & Mean & Std. Deviation \\
\hline Speaking & 30 & 40 & 94 & 1835 & 61.17 & 14.601 \\
Competency (Y) & 30 & 30 & 70 & 1527 & 50.90 & 9.607 \\
Podcast (X) & 30 & & & & & \\
Valid N (listwise) & & & & \\
\hline
\end{tabular}

The table shows that the total data of the speaking competency variable (Y) score is 1835. The mean score is 61.17 , the minimum score is 40 , the maximum score is 94 , and the standard deviation is 14.601 . Then the total data of the podcast variable $(\mathrm{X})$ score is 1527 . The mean score is 50.90 , the minimum score is 30 , the maximum score is 70 , and the standard deviation is 9,607 . 


\section{Inferential Analysis \\ Normality Test}

A Normality test is a test to find out whether the data normally distributed or not. According to Thode (2002:1) normality test is one of the most common assumption made in the development and use of statistical procedures. This correlation used the One-Sample Kolmogorov-Smirnov test by SPSS. Data is considered as normally distributed if the value Sig.(2-tailed) $>0,05$.

Table 2 Normality Test

One-Sample Kolmogorov-Smirnov Test

\begin{tabular}{|ll|r|}
\hline & & Unstandardized Residual \\
\hline $\mathrm{N}$ & & 30 \\
Normal Parameters ${ }^{\mathrm{a}, \mathrm{b}}$ & Mean & .0000000 \\
& Std. & 9.58540059 \\
& Deviation & .141 \\
Most Extreme Differences & Absolute & .097 \\
& Positive & -.141 \\
& Negative & .141 \\
Test Statistic & & $.130^{\mathrm{c}}$ \\
\hline
\end{tabular}

a. Test distribution is Normal.

b. Calculated from data.

c. Lilliefors Significance Correction.

The table shows that the significance value of Asymp. Sig. (2-tailed) 0,130>0,05 for both data of EFL learners' speaking competency (Y) and the use of podcast (X). It concludes that EFL learners' speaking competency $(\mathrm{Y})$ and the use of podcast $(\mathrm{X})$ has a normal distribution.

\section{Linearity Test}

A Linearity test is a test to determine whether the independent variable and dependent variable have a significant relationship or not. The variables considered have a significant linear correlation if the deviation from the linearity significance value is greater than 0,05 .

Table 3 Linearity Test.

ANOVA Table

\begin{tabular}{|c|c|c|c|c|c|c|c|}
\hline & & & $\begin{array}{c}\text { Sum of } \\
\text { Squares }\end{array}$ & $\mathrm{df}$ & $\begin{array}{l}\text { Mean } \\
\text { Square }\end{array}$ & $\mathrm{F}$ & Sig. \\
\hline \multirow{5}{*}{$\begin{array}{l}\text { Speaking } \\
\text { Competency } \\
\text { (Y) * Podcast } \\
\text { (X) }\end{array}$} & Betwee & (Combined) & 4722.167 & 18 & 262.343 & 1.977 & .125 \\
\hline & $\begin{array}{l}\mathrm{n} \\
\text { Groups }\end{array}$ & & 3517.649 & 1 & $\begin{array}{r}3517.64 \\
9\end{array}$ & 26.503 & .000 \\
\hline & & $\begin{array}{l}\text { Deviation } \\
\text { from } \\
\text { Linearity }\end{array}$ & 1204.517 & 17 & 70.854 & .534 & .881 \\
\hline & \multicolumn{2}{|c|}{ Within Groups } & 1460.000 & 11 & 132.727 & & \\
\hline & \multicolumn{2}{|l|}{ Total } & 6182.167 & 29 & & & \\
\hline
\end{tabular}

The table above shows that linearity value $0,881>0,05$. It can be concluded that there is a significant linear between the speaking competency variable $(\mathrm{Y})$ and podcast variable $(\mathrm{X})$. 


\section{Simple Linear Regression Test}

A simple linear regression test is a test to know whether there is a positive or negative correlation between the independent and dependent variables.

Table 4 Simple Linear Regression Test

Coefficients $^{\mathbf{a}}$

\begin{tabular}{|c|c|c|c|c|c|c|}
\hline \multirow{2}{*}{\multicolumn{2}{|c|}{ Model }} & \multicolumn{2}{|c|}{$\begin{array}{c}\text { Unstandardized } \\
\text { Coefficients }\end{array}$} & \multirow{2}{*}{$\begin{array}{c}\begin{array}{c}\text { Standardized } \\
\text { Coefficients }\end{array} \\
\text { Beta }\end{array}$} & \multirow[b]{2}{*}{$\mathrm{t}$} & \multirow[b]{2}{*}{ Sig. } \\
\hline & & B & Std. Error & & & \\
\hline & (Constant) & 2.816 & 9.761 & & .289 & .775 \\
\hline & $\begin{array}{l}\text { Podcast } \\
\text { (X) }\end{array}$ & 1.146 & .189 & .754 & 6.080 & .000 \\
\hline
\end{tabular}

a. Dependent Variable: Speaking Competency (Y)

The table shows that the value of constant is 2.816 and coefficient regression is 1.146 . The regression equation is:

$$
\begin{gathered}
\mathrm{Y}=\mathrm{a}+\mathrm{bX} \\
\mathrm{Y}=2.816+1.146 \mathrm{X}
\end{gathered}
$$

The simple regression equation can be concluded as follows:

a) The value of constant 2.816 means that if the speaking competency variable (Y) score is 0 , then the podcast variable $(\mathrm{X})$ score is 2.816 .

b) The Regression coefficient value of speaking competency (Y) is 1.146. It states that every $1 \%$ change in the value of speaking competency, the value of podcast increases by 1.146. It can be concluded that the regression coefficient is positive. The higher of using podcasts, the more speaking competence of EFL learners will increase.

\section{Determination Coefficient Test $\left(\mathbf{R}^{2}\right)$}

A Determination test is a test to find how much the influence between independent variable (X) and dependent variable (Y). The following is the value of the determination coefficient:

Table 5 Coefficient Determination Test Model Summary ${ }^{b}$

\begin{tabular}{|l|c|r|r|r|}
\hline Model & R & R Square & $\begin{array}{c}\text { Adjusted R } \\
\text { Square }\end{array}$ & $\begin{array}{c}\text { Std. Error of } \\
\text { the Estimate }\end{array}$ \\
\hline 1 & $.754^{\mathrm{a}}$ & $\mathbf{. 5 6 9}$ & .554 & 9.755 \\
\hline
\end{tabular}

a. Predictors: (Constant), Podcast (X)

b. Dependent Variable: Speaking Competency (Y)

The table shows that the determination coefficient ( $\mathrm{R}$ Square) value is 0.569 or $56,9 \%$. It means the use of podcast contributes 56,9\% to EFL learners speaking competency. The rest of 43,1\% is influenced by other variables that not discussed in this research.

\section{Hypothesis Test}

Hypothesis test is a test to determine whether there is a correlation between the speaking competency (Y) and podcast (X) using the partial hypothesis test (t-test). A Partial hypothesis test ( $\mathrm{t}$-test) is a test determine the effect of each independent variable $\mathrm{X}$ on the dependent variable Y. 
Table 6 Coefficient Determination Test

Coefficients

\begin{tabular}{|c|c|c|c|c|c|c|}
\hline \multirow{2}{*}{\multicolumn{2}{|c|}{ Model }} & \multicolumn{2}{|c|}{$\begin{array}{c}\text { Unstandardized } \\
\text { Coefficients }\end{array}$} & $\begin{array}{l}\text { Standardized } \\
\text { Coefficients }\end{array}$ & \multirow[b]{2}{*}{ ( } & \multirow[b]{2}{*}{ Sig. } \\
\hline & & B & Std. Error & Beta & & \\
\hline & (Constant) & 2.816 & 9.761 & & .289 & .775 \\
\hline & $\begin{array}{l}\text { Podcast } \\
\text { (X) }\end{array}$ & 1.146 & .189 & .754 & 6.080 & .000 \\
\hline
\end{tabular}

a. Dependent Variable: Speaking Competency (Y)

The following are testing steps:

1) Determine the hypothesis

Ha: There is correlation between EFL learners' speaking competency and the use of podcasts

Ho: There is correlation between EFL learners' speaking competency and the use of podcasts

2) Determine the level of significance

A standard level of significance is 0,05

3) Determine t-value

From the coefficient table, it shows that $\mathrm{t}$-value is 6.080

4) Determine t-table

$\mathrm{t}$-table is obtained using the formula (df) $\mathrm{n}-\mathrm{k}-1$. The total of the sample (n) is 30 people and the total of variable $(\mathrm{k})$ is 2 , so that obtained $(\mathrm{df}) 30-2-1=27$. With 2 -sided testing (Significance $=0.025$ ) the result for the $\mathrm{t}$ table is 2,051

5) Testing criteria

Ho is rejected dan $\mathrm{Ha}$ is accepted, if $\mathrm{t}$ value $>\mathrm{t}$ table or significance value $<0.05$

Ho is accepted dan $\mathrm{Ha}$ is rejected, if $\mathrm{t}$ value $<\mathrm{t}$ table or significance value $>0.05$

\section{Comparing $t$ value with $t$ table}

$\mathrm{t}$ value is greater than $\mathrm{t}$ table $(6.080>2,05)$. It means Ho is rejected.

\section{CONCLUSION}

From the determination of the test above, it proves that $\mathrm{Ho}$ is rejected and $\mathrm{Ha}$ is accepted. There is a positive correlation between EFL learners' speaking competency and the use of podcast. It is based on the $t$ value which is greater than t table $(6.080>2,05)$ with the level of significance $0,000<0,05$.

\section{Discussion on Finding}

The description above shows that there is a correlation between EFL learners' speaking competency and the use of podcast of eleventh grade students of Mutiara 17 Agustus Vocational High School Bekasi. The result of hypothesis test using t-test, the t-value is higher than $t$-table $(6.080>2,05)$ at the level of significant 0,05 . It means that there is a positive correlation between EFL learners' speaking competency and the use of podcast. The coefficient (R Square) between both of variables is high. The use of podcasts contributes $56,9 \%$ and gives a positive correlation to EFL learners' speaking competency. The rest of $43,1 \%$ is influenced by other variables that not discussed in this research. Therefore, null hypothesis $\left(\mathrm{H}_{\mathrm{o}}\right)$ is rejected and the alternate hypothesis $\left(\mathrm{H}_{\mathrm{a}}\right)$ is accepted. In other words, using podcast is one of the methods in order to develop EFL learners' speaking competency. 


\section{BIBLIOGRAPHY}

Chaikovska, O., Zbaravska, L., \& Bilyk, T. (2019). Podcasts in teaching EFL for students majoring in engineering. In Proceedings of 18th International Scientific Conference "Engineering for Rural Development (pp. 1915-1920).

Derakhshan, A., Khalili, A.N., \& Beheshti,F. 2016. Developing EFL Learner's Speaking Ability, Accuracy and Fluency. English Language and Literature Studies, 6 (2), 178.

Dewi, R. S., Kultsum, U., \& Armadi, A. (2017). Using Communicative Games in Improving Students' Speaking Skills. English Language Teaching, 10(1), 63-71.

Drew, C. (2017). Educational podcasts: A genre analysis. E-Learning and Digital Media, 14(4), 201-211.

Jabbarova, A. (2020). The Importance Of Evaluating Students'speaking Skills. Архив Научныхх Публикаџий JSPI.

Leong, L. M., \& Ahmadi, S. M. (2017). An Analysis Of Factors Influencing Learners'english Speaking Skill.

Ounis, A. (2017). The assessment of speaking skills at the tertiary level. International Journal of English Linguistics, 7(4), p95.

Parmawati, A., \& Inayah, R. (2019). Improving Students'speaking Skill Through English Movie In Scope Of Speaking For General Communication. Eltin Journal, Journal Of English Language Teaching In Indonesia, 7(2), 43-53.

Rahman, M. M. (2010). Teaching oral communication skills: A task-based approach. ESP world, 9(1), 1-11.

Ramli, (2018). The Use of Podcast to Improve Students' Listening and Speaking Skills for EFL Learners. Journal of Applied Linguistics and Language Research Vol 5(2),4.

Rao, P. S. (2019). The role of English as a global language. Research Journal of English, 4(1), 65-79.

Rao, P. S. (2019). The importance of speaking skills in English classrooms. Alford Council of International English \& Literature Journal (ACIELJ), 2(2), 6-18.

Riadil, I. G. (2020). A Study of Students' Perception: Identifying EFL Learners' Problems in Speaking Skill. International Journal of Education, Language, and Religion, 2(1), 3138.

Sze, Paul. (2006). The Chinese University of Hongkong: Developing Students' Listening and Speaking Skills through ELT Podcasts. Educational Journal Vol (34).2.

Thode, Henry C. 2002. Testing For Normality. Bosa Roca: Taylor \& Francis Inc.

Ur, Penny. 2012. A Course in Language Teaching: Practice and Theory. 2nd ed. Cambridge: Cambridge University Press. 